\title{
Metformin reduces the expression of NADPH oxidase and increases the expression of antioxidative enzymes in human monocytes/macrophages cultured in vitro
}

\author{
ŁUKASZ BUŁDAK $^{1}$, KRZYSZTOF ŁABUZEK ${ }^{1}$, RAFAŁ JAKUB BUŁDAK ${ }^{2}$, GRZEGORZ MACHNIK ${ }^{1}$, \\ ALEKSANDRA BOŁDYS $^{1}$, MARCIN BASIAK ${ }^{1}$ and OKOPIEŃ BOGUSŁAW ${ }^{1}$
}

\begin{abstract}
${ }^{1}$ Department of Internal Medicine and Clinical Pharmacology, School of Medicine in Katowice, Medical University of Silesia, Katowice 40-752; ${ }^{2}$ Department of Physiology, School of Medicine with the Division of Dentistry in Zabrze, Medical University of Silesia, Zabrze 41-808, Poland
\end{abstract}

Received January 11, 2015; Accepted September 25, 2015

DOI: $10.3892 /$ etm.2016.2977

\begin{abstract}
The treatment of diabetes and its complications is a key challenge for healthcare professionals. Accelerated atherosclerosis is associated with progressive diabetes, and it has been indicated that macrophages serve a crucial function in this process. Currently, the first-line treatment of diabetes is based on metformin, which is an inducer of AMP-activated protein kinase (AMPK) and belongs to the biguanide class of pharmaceuticals. It has been previously demonstrated that metformin exhibits more than just hypoglycemic effects. Therefore, the aim of the present study was to investigate the in vitro impact of metformin on cell viability and the expression levels of nicotinamide adenine dinucleotide phosphate (NAPDH) oxidase (p22 $\left.{ }^{\text {phox }}\right)$, a major enzyme in reactive oxygen species generation, and the three antioxidative enzymes superoxide dismutase (SOD), glutathione peroxidase (GPx) and catalase (CAT) in monocytes/macrophages derived from 10 healthy volunteers. The effects of metformin were observed in the presence or absence of lipopolysaccharide (LPS), which was administered to induce oxidative stress. Furthermore, certain cells were treated with compound $\mathrm{C}$, an inhibitor of AMPK, in order to determine the mechanistic role played by AMPK in the oxidative changes in the macrophages. Cell viability was evaluated using trypan blue and MTT assays. The mRNA and protein expression levels of $\mathrm{p} 22^{\text {phox }}$ and the various antioxidative enzymes were determined using polymerase chain reaction and western blot analysis, respectively. The results indicated that metformin, predominantly in LPS-pretreated
\end{abstract}

Correspondence to: Dr Łukasz Bułdak, Department of Internal Medicine and Clinical Pharmacology, School of Medicine in Katowice, Medical University of Silesia, 18 Medykow, Katowice 40-752, Poland

E-mail: lbuldak@gmail.com

Key words: macrophages, metformin, oxidative stress, reactive oxygen species monocytes/macrophages, reduced the expression levels of p $22^{\text {phox }}$ and increased those of SOD and GPx, but had only a minor effect on CAT levels. Therefore, metformin appears to alter the oxidative status of macrophages toward increasingly antioxidative activity, which may account for the pleiotropic effects observed during metformin treatment.

\section{Introduction}

Oxidative stress is a crucial factor in the pathogenesis of atherosclerosis. Key cells in this process include macrophages, which are responsible for production of reactive oxygen species (ROS). Oxidative burst is a key process performed by the innate immune system for mitigating infections. During acute infectious illnesses, inflammatory cells generate increased quantities of ROS to eliminate the invading pathogen. Subsequently, a reduction of inflammation is observed, which is accompanied by a shift from classical to alternative activation of macrophages. This process is characterized by a reduction in the synthesis of inflammatory cytokines and ROS and increased synthesis of enzymes associated with tissue repair and scar formation (1). Low-grade inflammation, which is accompanied by oxidative stress, is detected in patients suffering from various diseases including diabetes (2), obesity (3), coronary heart disease (4) and hypertension (5). This condition is frequently associated with a minute elevation in serum levels of high-sensitivity C-reactive protein (hsCRP), which is in turn associated with an increased risk of cardiovascular complications (6). Therapies that pleiotropically reduce inflammation, such as statins, may reduce levels of CRP (7) and improve cardiovascular outcomes (8). Additionally, a reduction in oxidative stress level may be observed, which is accompanied by a reduction in nicotinamide adenine dinucleotide phosphate (NADPH) oxidase (p22 ${ }^{\text {phox }}$ ) activity $(9,10)$.

Type 2 diabetes is a growing health problem in modern societies. Diabetes markedly accelerates the development of atherosclerosis, which results from increased oxidative stress, the glycation of proteins and insulin resistance accompanied by hyperinsulinemia. In the treatment of diabetes, metformin has become the drug of choice due to its ability to improve 
insulin sensitivity and effectively reduce glycemia without a significant increase in hypoglycemia event rate. In a large multi-center trial conducted by the UK Prospective Diabetes Study group, metformin induced a significant reduction in the cardiovascular complications of patients with diabetes; however, it appeared that the treatment produced activities other than just hypoglycemic effects (11). This observation may stem from the attenuation of the inflammatory state and reduced ROS generation resulting from $\mathrm{p} 22^{\text {phox }}$, which is a major source of ROS, or the increased expression of antioxidative enzymes that eliminate ROS. ROS may damage cellular DNA, and alter proteins (e.g., enzymes) and lipids resulting in accelerated atherosclerosis or carcinogenesis $(12,13)$. The impact of ROS on inflammatory potential in smooth muscles, endothelial cells and macrophages has been explored (14). However, the effect of metformin on the expression of antioxidative enzymes in human macrophages has not been fully investigated. There are three primary antioxidative enzymes that regulate ROS. Superoxide dismutase (SOD) synthesizes $\mathrm{H}_{2} \mathrm{O}_{2}$ from highly reactive peroxides. Excessive $\mathrm{H}_{2} \mathrm{O}_{2}$ may be mitigated by glutathione peroxidase (GPx), which utilizes glutathione, or by catalase (CAT), which produces water and oxygen from two molecules of $\mathrm{H}_{2} \mathrm{O}_{2}$ (14).

The primary mechanism of action of metformin is based on the activation of AMP-dependent kinase (AMPK). AMPK is a serine/threonine kinase involved in cellular metabolism, fatty acid oxidation and energy expenditure and conservation. Circulating monocytes/macrophages express AMPK and thus actively participate in atherogenesis and oxidative stress. In our previous study, it was demonstrated that metformin induced the alternative (anti-inflammatory) phenotype in macrophages and reduced oxidative stress, as indicated by decreased ROS levels, which was accompanied by increased antioxidative enzyme activity (1). The aim of the present study was to investigate the influence of metformin on the expression levels of $\mathrm{p} 22^{\text {phox }}$ (a major source of ROS) and SOD, GPx and CAT (three enzymes connected with the cellular anti-inflammatory properties) in human monocytes/macrophages cultured in vitro.

\section{Materials and methods}

Cell culture. A total of 10 healthy volunteers (age, 18-40 years; 5 women and 5 men) were recruited for the study from the Department of Internal Medicine and Clinical Pharmacology (Medical University of Silesia, Silesia, Poland) all of whom were nonsmokers and were taking no medication. The ethical committee of the Medical University of Silesia accepted the study protocol. Peripheral blood mononuclear cells were extracted from the patients using Histopaque density gradient centrifugation (Sigma-Aldrich, St. Louis, MO, USA), using previously described methods (15). Subsequently, monocytes were isolated from the peripheral blood mononuclear cells via negative immunomagnetic separation, using Pan-T and Pan-B Dynabeads (Invitrogen Dynal AS, Oslo, Norway), according to the manufacturer's instructions. This procedure enabled the isolation of inactive monocytes without the use of artificial and uncontrolled stimulation. The isolated cells were labeled with a mouse anti-human monoclonal antibody (dilution, 1:100; F0844; Dako Denmark A/S, Glostrup, Denmark) against the monocyte-specific positive antigen $\mathrm{CD} 14^{+}$. The procedure resulted in an isolated fraction containing $92 \% \mathrm{CD}^{+} 4^{+}$cells. Monocytes were suspended in RPMI-1640 medium supplemented with $10 \%$ low endotoxin fetal calf serum, $2 \mathrm{mM}$ glutamine, $100 \mathrm{U} / \mathrm{ml}$ penicillin, $100 \mathrm{mg} / \mathrm{ml}$ streptomycin and $10 \mathrm{mg} / \mathrm{ml}$ Gibco fungizone (Thermo Fisher Scientific, Inc., Grand Island, NY, USA). The cells were counted using a TC-20 automated cell counter (Bio-Rad Laboratories, Inc., Hercules, CA, USA). A constant number of cells $\left(10^{6}\right.$ monocytes per well) were placed in a plastic 24-well plate (BD Biosciences, Franklin Lakes, NJ, USA) and left intact for $2 \mathrm{~h}$ for adherence. Then, the medium was changed and cultures were incubated for $72 \mathrm{~h}$, with a single exchange of medium after the first $24 \mathrm{~h}$. Incubations were performed in triplicate at $37^{\circ} \mathrm{C}$ in a humidified atmosphere containing $5 \% \mathrm{CO}_{2}$. The conversion of monocytes into macrophages was confirmed using polyclonal mouse antibodies against EMR1 (1:1,000; SAB1405756; Sigma-Aldrich). Following the 72-h incubation, the supernatant was carefully removed and replaced with medium supplemented with various combinations of metformin (0.02 or $2 \mathrm{mM}$; Sigma-Aldrich), compound C (20 $\mu \mathrm{M}$; Sigma-Aldrich) or lipopolysaccharide (LPS; $1 \mu \mathrm{g} / \mathrm{ml}$; Sigma-Aldrich) for $24 \mathrm{~h}$. Certain cells were pre-incubated with metformin $(0.02$ or $2 \mathrm{mM})$ for $2 \mathrm{~h}$ to activate AMPK, then LPS $(1 \mu \mathrm{g} / \mathrm{ml})$ was added for $24 \mathrm{~h}$. Certain cells were pre-incubated with compound $\mathrm{C}(20 \mu \mathrm{M})$ for $1 \mathrm{~h}$ to inhibit AMPK, then metformin $(0.02$ or $2 \mathrm{mM})$ was added. Following an additional $2 \mathrm{~h}$, LPS was administered for $24 \mathrm{~h}$. Compound C, at an initial concentration of $20 \mathrm{mM}$, was dissolved in dimethyl sulfoxide (DMSO; Sigma-Aldrich). A total of nine groups were thus produced, as follows: Control group (no treatment); LPS group; compound $\mathrm{C}$ group; $0.02 \mathrm{mM}$ metformin group; $2.0 \mathrm{mM}$ metformin group; compound $\mathrm{C}+2.0 \mathrm{mM}$ metformin group; LPS + $0.02 \mathrm{mM}$ metformin group; LPS $+2.0 \mathrm{mM}$ metformin group; and the LPS + compound $\mathrm{C}+2.0 \mathrm{mM}$ metformin group. Further dilutions were performed in the aforementioned RPMI medium and the corresponding quantities of DMSO were added to the control cultures. The final concentration of DMSO in the medium was $\leq 0.05 \%$ and, as previously confirmed, did not exert any effects on the cultured cells (16). Following the application of the various treatments, the cells were harvested for further analyses. Each group of experiments was performed in triplicate (17).

Viability tests. The cell viability was estimated using two tests. The first was based on a $0.4 \%$ trypan blue exclusion test (Sigma-Aldrich), according to manufacturers guidelines. Briefly, 10- $\mu 1$ aliquots of cultured cells suspended in RPMI medium with no additions were mixed with $10 \mu 10.4 \%$ trypan blue. Following incubation for $3 \mathrm{~min}$ at $37^{\circ} \mathrm{C}$, the cells were loaded onto a slide and the viability was assessed using the TC-20 automated cell counter. The second method involved MTT conversion (1). MTT was added to the medium (at a final concentration of $2.5 \mathrm{mg} / \mathrm{ml}$ ) $3 \mathrm{~h}$ prior to the scheduled end of the experiment, then the cultures were incubated at $37^{\circ} \mathrm{C}$ in $5 \%$ $\mathrm{CO}_{2} / 95 \%$ air. At the end of the experiment, after being washed twice with phosphate-buffered saline, monocytes were lysed in $100 \mu \mathrm{l}$ DMSO at room temperature for $10 \mathrm{~min}$ in the dark, which enabled the release of the blue reaction product formazan. Then, $200 \mu 1$ lysate was transferred to a 96-well plate (Falcon 353072; BD Biosciences). Absorbance was measured at $570 \mathrm{~nm}$ using a 
microplate reader (Dynex Technologies, Chantilly, VA, USA) using three measurements in each of ten independent experiments. The results are expressed as a percentage of the control.

Reverse transcription-quantitative polymerase chain reaction $(R T-q P C R)$. The relative mRNA expression levels of GPx, CAT,

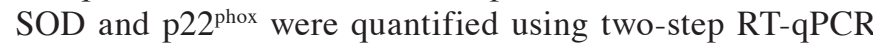
normalized against the expression level of glyceraldehyde 3-phosphate dehydrogenase (GAPDH) mRNA following $8 \mathrm{~h}$ of incubation. Total RNA was extracted from cells using TriPure Isolation Reagent (Roche Diagnostics, Basel, Switzerland) according to the manufacturer's instructions. The concentration and quality of the RNA extracts were estimated using spectrophotometry at 260 and $280 \mathrm{~nm}$ using a BioPhotometer (Eppendorf AG, Hamburg, Germany). Subsequently, $1 \mu \mathrm{g}$ total RNA of each sample was reverse transcribed using an MMLV Reverse Transcriptase 1st-Strand cDNA Synthesis kit (Epicentre Technologies, Madison, WI, USA). A final RT reaction volume of $20 \mu 1$ was diluted 5 -fold in order to avoid possible reaction inhibition by high levels of cDNA. The qPCR was conducted using Brilliant II SYBR Green QRT-PCR 2-Step Master mix (Agilent Technologies, Inc., Santa Clara, CA, USA). Reaction mixtures consisted of $1 \mathrm{X}$ master mix, $300 \mathrm{nM}$ of each (forward and reverse) primer complementary to one of the analyzed genes (GPx, CAT, SOD, p22 $2^{\text {phox }}$ or GAPDH), respectively, $4 \mu \mathrm{l}$ cDNA mixture (i.e., an equivalent of $40 \mathrm{ng}$ total RNA) in a total volume of $25 \mu \mathrm{l}$. The reaction mixtures were analyzed using a LightCycler 480 Real-Time PCR system (Roche Diagnostics) with a standard two-step thermal profile for qPCR: $95^{\circ} \mathrm{C}$ for $2 \mathrm{~min}$, then 40 cycles of $95^{\circ} \mathrm{C}$ for $15 \mathrm{sec}$ and $60^{\circ} \mathrm{C}$ for $30 \mathrm{sec}$. Following amplification, a melting curve was plotted for each sample in order to confirm the specificity of the reaction. Primers used for quantitative analysis were designed using eprimer3 software produced by European Molecular Biology Open Software Suite (EMBOSS; http://emboss. bioinformatics.nl/cgi-bin/emboss/eprimer3) according to the appropriate gene retrieved from the GenBank database (http://www.ncbi.nlm.nih.gov/genbank/) and were similar to those used in previous experiments: p22, forward 5'-TCC GGCCTGATCCTCATC-3' and reverse 5'-AATGGAGTA GGCACCAAAGTACCA-3'; SOD, forward 5'-CTGATT TGGACAAGCAGCAA-3' and reverse 5'-CTGGACAAA CCTCAGCCCTA-3'; GPx, forward 5'-CGGGACTACACC CAGATGAA-3' and reverse 5'-TCTCTTCGTTCTTGG CGTTC-3'; CAT, forward 5'-TCAGGCAGAAACTTTTCC ATTT-3' and reverse 5'-TGGGTCGAAGGCTATCTGTT-3'; and GAPDH, forward 5'-GAAGGTGAAGGTCGGAGTC-3' and reverse 5'-GAAGATGGTGATGGGATTTC-3') (18-20). Eprimer3, Primersearch and Water software were used for primer design and comparisons and are freely available on the server of the Pasteur Institute (Paris, France http://mobyle. pasteur.fr) as a part of EMBOSS (21). Additionally, randomly selected samples derived from qPCR assays were loaded onto 1.3\% agarose gels (Agagel Mini; Biometra $\mathrm{GmbH}$, Göttingen, Germany) in order to confirm the specificity of amplification. No other bands than expected for a particular primer pair were visible.

Protein extraction and western blot analysis. Total protein concentrations in samples were determined spectrophotometrically. Bovine serum albumin preparations (Fermentas, Glen Burnie, MD, USA) were used for calculation of the standard curve. Equal quantities of total protein $(50 \mu \mathrm{g})$ mixed 1:1 with $2 \mathrm{X}$ sample buffer (25\% glycerol, $2 \%$ sodium dodecyl sulfate and $0.02 \%$ bromophenol blue) were boiled for 6 min and loaded onto a 10\% SDS-polyacrylamide gel (Sigma-Aldrich). Electrophoresis was performed at $180 \mathrm{~V}$ (constant voltage) until the bromophenol blue dye reached the end of the gel. Following electrophoresis, the stacking gels were removed and resolved, and sample gels were directly subjected to western blot analysis. After separation in polyacrylamide gels, the aliquots were transferred to polyvinylidene fluoride membranes (Pall Poland Ltd., Warszawa, Poland). Nonspecific antibody binding was inhibited by incubation in $20 \mathrm{mM}$ Tris-buffered saline (pH 7.5) with $0.1 \%$ Tween 20 (TBST) containing 5\% non-fat dried milk for $1 \mathrm{~h}$ at room temperature. Polyclonal antibodies against: $\mathrm{p} 22^{\text {phox }}, \mathrm{GPx}$, CAT and SOD were obtained from Sigma-Aldrich. The antibodies were diluted in TBST containing 5\% skimmed milk. The membranes were incubated with the antibodies overnight at $4^{\circ} \mathrm{C}$, washed with TBST, incubated at room temperature for $60 \mathrm{~min}$ with the appropriate goat anti-rabbit (1706518) and goat anti-mouse (1706520) alkaline phosphatase (AP)-conjugated secondary antibodies (1:1,000; Bio-Rad Laboratories Inc.) and washed twice with TBST for $5 \mathrm{~min}$ and once with $20 \mathrm{mM}$ Tris-buffered saline ( $\mathrm{pH}$ 7.8) for $5 \mathrm{~min}$. In each assay, the colored precipitates were developed directly on the membrane using AP-chromogenic substrates (Bio-Rad Laboratories, Inc.). All membranes were photocopied and subjected to further analysis. The molecular weights of GPx, CAT, SOD and p22 $2^{\text {phox }}$ were confirmed according to their protein markers (PageRuler Unstained Protein Ladder; Fermentas). To control for the quantities of cytosolic proteins loaded in each lane, $\alpha$-actin was detected in parallel using anti- $\alpha$-actin antibodies (1:5,000; ab8227; Abcam, Cambridge, MA, USA). The integrated optical density (IOD) of signals was semi-quantified using Image-Pro Plus software, version 3.0 (Media Cybernetics, Inc., Rockville, MD, USA) and is expressed as the ratio of the IOD for the tested proteins to the IOD for $\alpha$-actin. The experiment was repeated three times, and the relative density values were subjected to statistical analysis.

Statistical analysis. Results are expressed as the mean \pm standard deviation. The normality of distribution was tested using Shapiro-Wilk's test. Statistical analysis of the data was performed using one-way analysis of variance followed by the post-hoc Tukey's significant difference test or Kruskal-Wallis test with Mann-Whitney tests according to the distribution of variables. The Bonferroni adjustment was applied for multiple comparisons. $\mathrm{P}<0.05$ was considered to indicate a statistically significant difference. Statistical analysis was performed using a SPSS software, version 16.0 (SPSS, Inc., Chicago, IL, USA).

\section{Results}

LPS, compound $C$ and metformin do not affect cell viability. No significant differences in cell viability were observed among the cultures regardless of the reagents with which they were treated (Fig. 1). 
Viability test ( $0.4 \%$ trypan blue exclusion test)

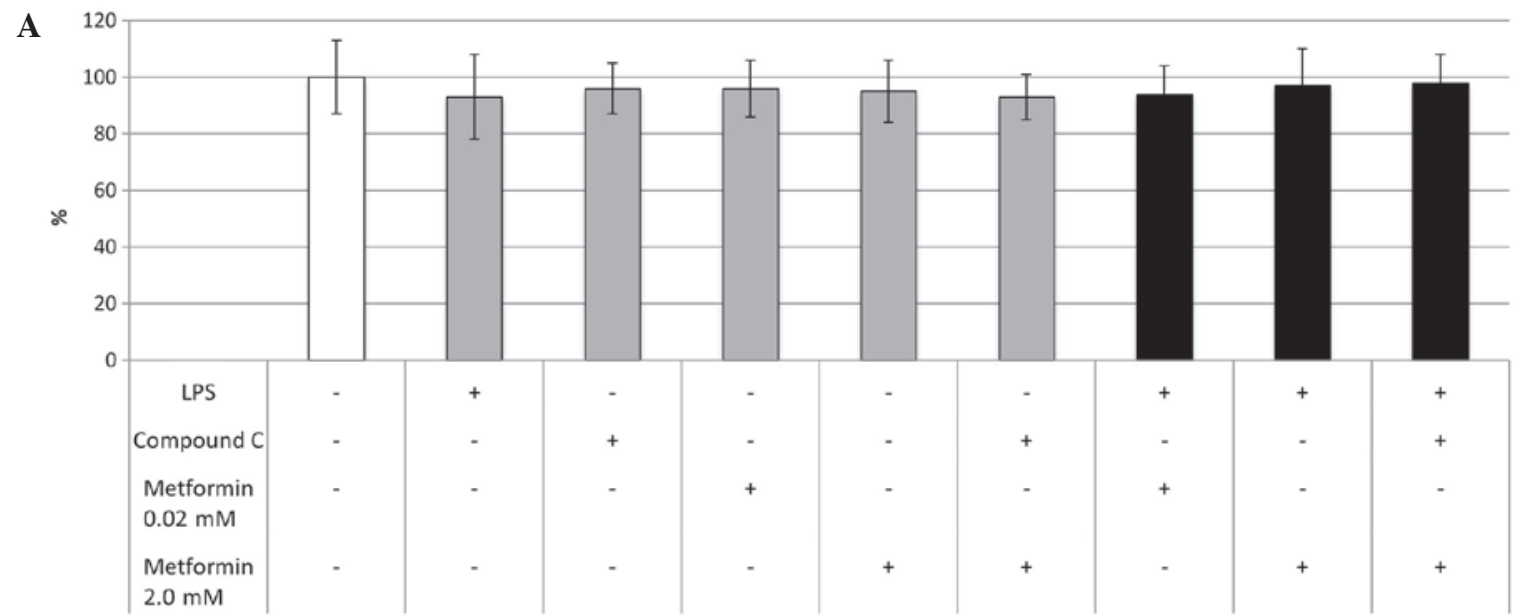

Viability test (MTT)

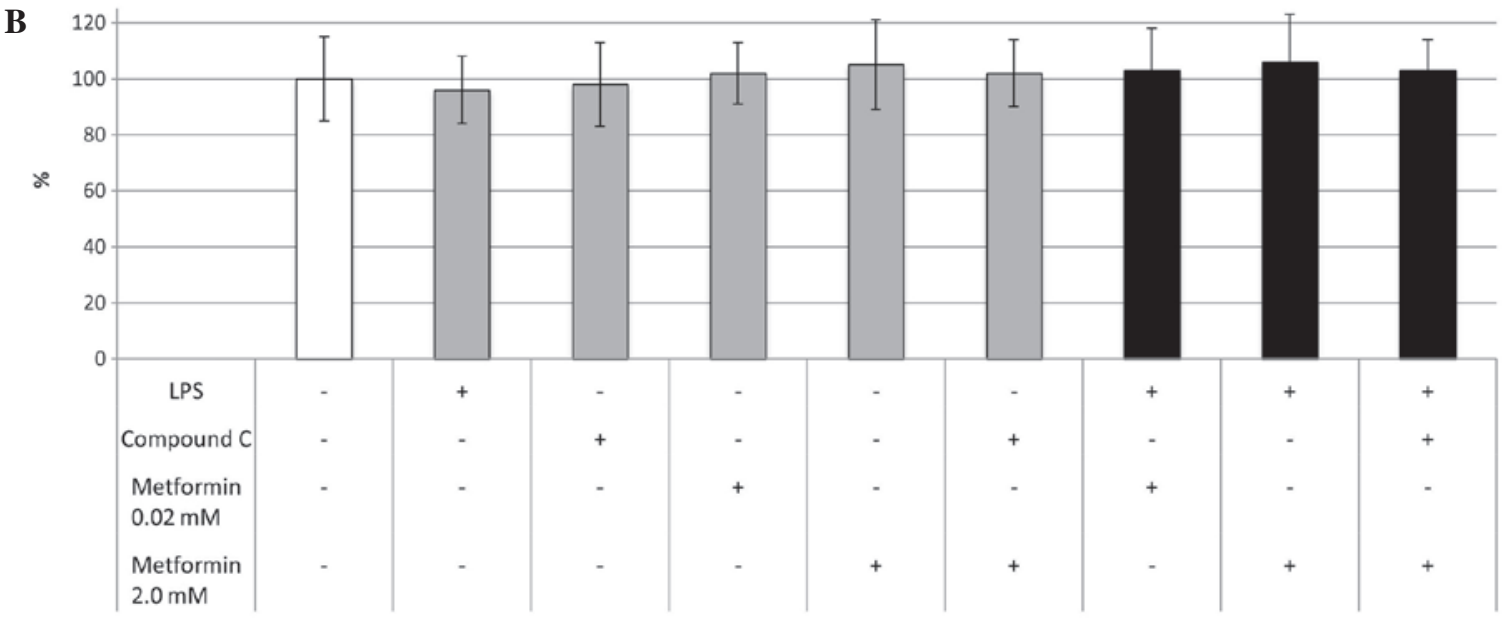

Figure 1. Viability of cultured monocytes/macrophages assessed using (A) $0.4 \%$ trypan blue exclusion and (B) MTT tests. LPS, lipopolysaccharide.

Effects of LPS, compound $C$ and metformin on $p 22^{\text {phox }}$. LPS significantly elevated the expression of $\mathrm{p} 22^{\text {phox }}$ at the mRNA $(6.34 \pm 0.56$ vs. $1.0 \pm 0.21$-fold; $\mathrm{P}<0.001)$ and protein $(7.23 \pm 1.45$ vs. $1.0 \pm 0.26$-fold; $\mathrm{P}<0.001)$ levels compared with that in the control group (Fig. 2). Metformin at a low concentration $(0.02 \mu \mathrm{M})$ did not significantly alter the mRNA expression levels of $\mathrm{p} 22^{\text {phox }}(1.12 \pm 0.23$ vs. 1.0 \pm 0.21 -fold; $\mathrm{P}=0.217)$; however, a high concentration of metformin $(2.0 \mu \mathrm{M})$ resulted in the elevation of mRNA expression levels $(1.43 \pm 0.15$ vs. $1.0 \pm 0.26$-fold; $\mathrm{P}=0.041)$ compared with those in the control. The protein expression levels of p22 $2^{\text {phox }}$ were not significantly affected by 0.02 or $2.0 \mathrm{mM}$ metformin. In the LPS-treated macrophages, $0.02 \mathrm{mM}$ metformin did not significantly alter the mRNA or protein expression levels of p22 ${ }^{\text {phox }}$. By contrast, $2.0 \mathrm{mM}$ metformin induced a significant reduction in the mRNA $(4.56 \pm 0.41$ vs. $6.34 \pm 0.56 ; \mathrm{P}=0.007)$ and protein $(5.33 \pm 0.94$ vs. $7.23 \pm 1.45 ; \mathrm{P}=0.002)$ expression levels of $\mathrm{p} 22^{\mathrm{phox}}$ in the LPS-treated macrophages. The addition of compound $\mathrm{C}$ significantly inhibited the effect of metformin on the mRNA $(5.95 \pm 0.39$ vs. $4.56 \pm 0.51 ; \mathrm{P}=0.011)$ and protein $(7.03 \pm 1.23$ vs. $5.33 \pm 0.94 ; \mathrm{P}=0.009)$ expression levels of $\mathrm{p} 22^{\text {phox }}$ in the LPS-treated cells. Following treatment with compound $\mathrm{C}$, these levels were comparable to those of the cells treated with LPS alone.

Effects of LPS, compound $C$ and metformin on SOD. LPS caused a small increase in the mRNA expression level of SOD $(1.32 \pm 0.19$ vs. $1.0 \pm 0.13 ; \mathrm{P}=0.038)$ compared with that in the control cells; however, it did not significantly change SOD protein expression (1.12 \pm 0.27 vs. 1.0 \pm 0.23 ) (Fig. 3). Metformin at $0.02 \mu \mathrm{M}$ significantly increased the mRNA expression level of SOD (1.4 \pm 0.21 vs. $1.0 \pm 0.13 ; \mathrm{P}=0.027)$, while $2.0 \mathrm{mM}$ metformin significantly elevated the mRNA $(1.8 \pm 0.18$ vs. $1.0 \pm 0.13$; $\mathrm{P}=0.006)$ and protein $(1.95 \pm 0.35$ vs. $1.0 \pm 0.23 ; \mathrm{P}=0.007)$ expression levels of SOD compared with those in the control group. The addition of $0.02 \mathrm{mM}$ metformin to LPS-treated cells resulted in a moderate increase in SOD mRNA expression (1.65 \pm 0.24 vs. $1.32 \pm 0.19 ; \mathrm{P}=0.009)$ compared with that in the cells treated with LPS alone. Metformin at $2.0 \mu \mathrm{M}$ produced a more marked difference in SOD mRNA expression (2.1 \pm 0.21 vs. $1.32 \pm 0.19$; $\mathrm{P}=0.005)$ in the LPS-treated cells. The effect of metformin on SOD protein concentration was particularly marked in the cells treated with $0.02 \mu \mathrm{M}(3.5 \pm 0.54$ vs. $1.12 \pm 0.27 ; \mathrm{P}<0.001)$ and $2.0 \mathrm{mM}$ metformin $(4.3 \pm 0.44$ vs. $1.12 \pm 0.27 ; \mathrm{P}<0.001)$, indicating 
p22 ${ }^{\text {phox }}$ (mRNA)

A

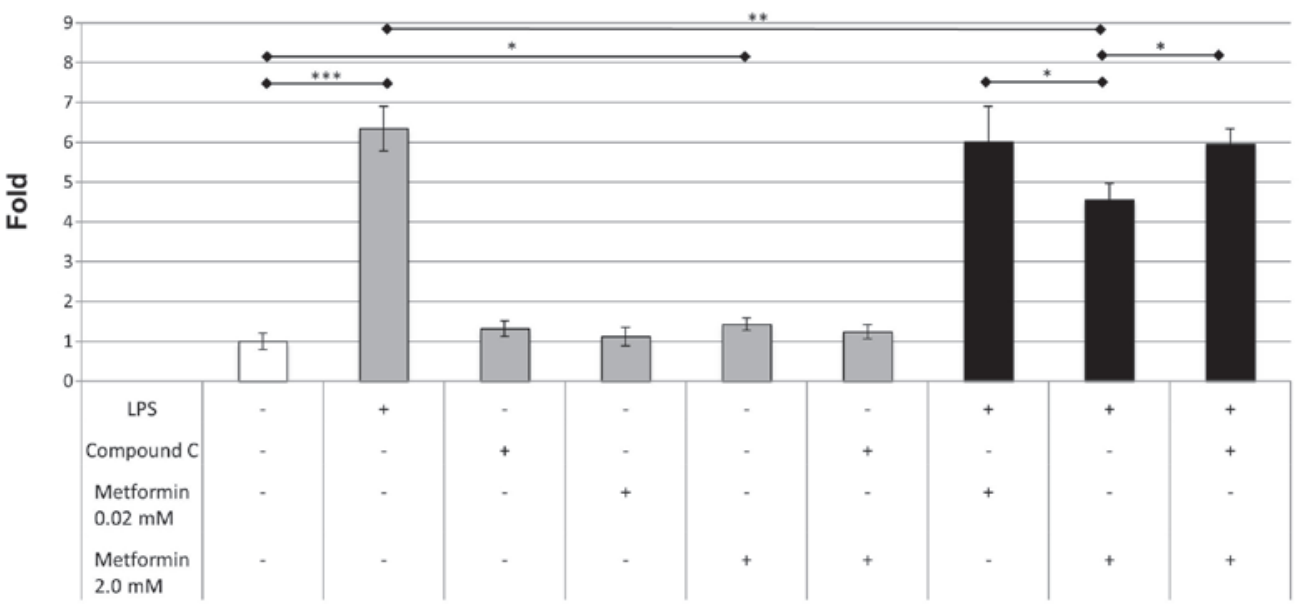

p22 ${ }^{\text {phox }}$ (protein)

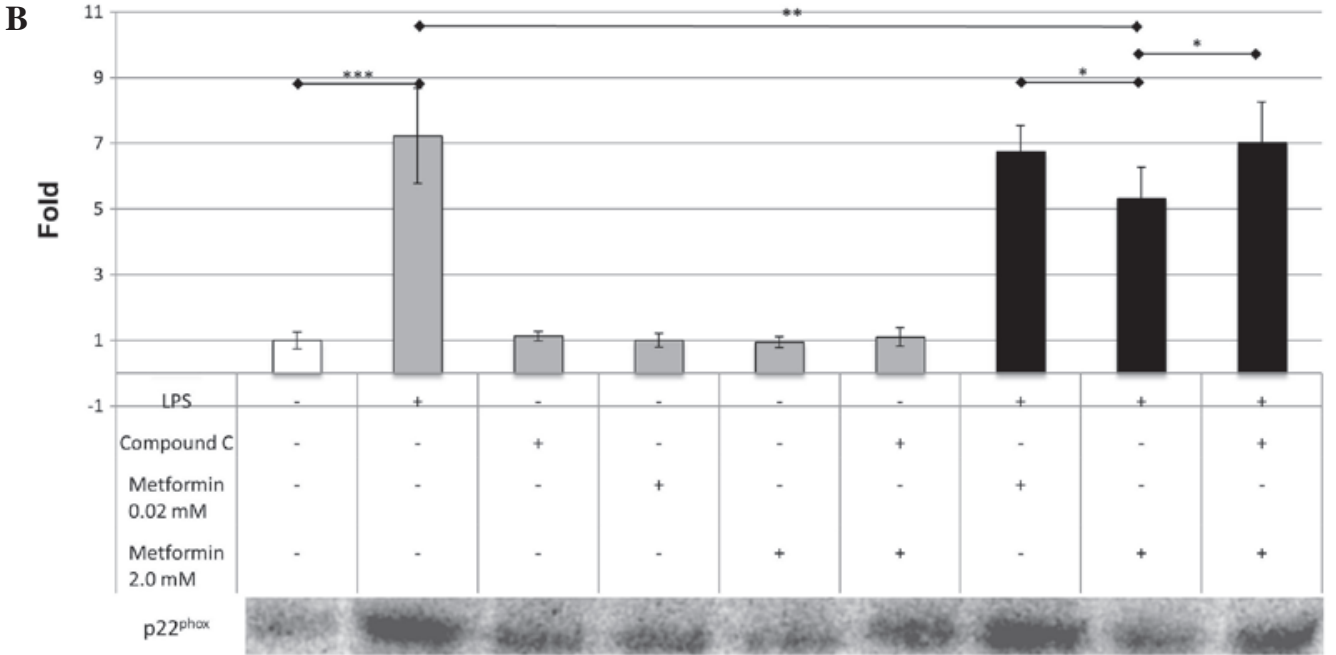

Figure 2. Influence of LPS, metformin and compound C on the expression of p22 NADPH oxidase mRNA and protein, assessed using (A) reverse transcription-quantitative polymerase chain reaction and (B) western blot analysis, respectively. ${ }^{*} \mathrm{P}<0.05 ;{ }^{* * *} \mathrm{P}<0.001 ;{ }^{* * * *} \mathrm{P}<0.001$. LPS, lipopolysaccharide; NADPH, nicotinamide adenine dinucleotide phosphate.

that metformin increases the expression of SOD more effectively in an inflammatory environment. Compound $\mathrm{C}$ reduced the effect of $2.0 \mathrm{mM}$ metformin on SOD mRNA (1.25 $\pm 0.28 \mathrm{vs}$. $2.1 \pm 0.21 ; \mathrm{P}=0.006)$ and protein $(1.4 \pm 0.23$ vs. $4.3 \pm 0.44 ; \mathrm{P}<0.001)$ expression levels, which resulted in mRNA expression levels similar to those of the LPS-treated macrophages $(1.25 \pm 0.28 \mathrm{vs}$. $1.32 \pm 0.19 ; \mathrm{P}=0.425)$; however, the protein expression levels of SOD remained slightly elevated $(1.4 \pm 0.23$ vs. $1.12 \pm 0.27$; $\mathrm{P}=0.048)$.

Effects of LPS, compound $C$ and metformin on GPX. Treatment with LPS increased the expression levels of GPx mRNA $(1.23 \pm 0.13$ vs. $1.0 \pm 0.24 ; \mathrm{P}=0.041)$ and protein $(1.84 \pm 0.21$ vs. $1.0 \pm 0.13 ; \mathrm{P}=0.002)$ compared with those in the control group (Fig. 4). In contrast to SOD, $0.02 \mathrm{mM}$ metformin did not significantly alter the mRNA or protein expression levels of GPx compared with those in the control group. However, $2.0 \mathrm{mM}$ metformin, similarly to its effect on SOD expression, increased the mRNA $(1.76 \pm 0.14$ vs. $1.0 \pm 0.24 ; \mathrm{P}=0.011)$ and protein $(1.72 \pm 0.43$ vs. $1.0 \pm 0.13 ; \mathrm{P}=0.016)$ expression levels of GPx compared with the control. The addition of $0.02 \mathrm{mM}$ metformin to the LPS-treated cells resulted in a significant increase in the mRNA $(1.43 \pm 0.17$ vs. $1.23 \pm 0.13 ; \mathrm{P}=0.038)$ and protein $(2.13 \pm 0.34$ vs. $1.84 \pm 0.21 ; \mathrm{P}=0.046)$ expression levels of GPx. Furthermore, $2.0 \mathrm{mM}$ metformin produced a more marked increase in the mRNA $(2.14 \pm 0.33$ vs. $1.23 \pm 0.13$; $\mathrm{P}=0.001)$ and protein $(2.56 \pm 0.22$ vs. $1.84 \pm 0.21 ; \mathrm{P}=0.003)$ expression levels of GPx in the LPS-treated cells. Experiments involving compound $\mathrm{C}$ and LPS indicated that metformin expressed its effects via AMPK, as a significant inhibitory influence of compound $\mathrm{C}$ on the expression of GPx mRNA and protein was observed. Following the AMPK inhibition, the GPx expression was comparable to that in samples treated only with LPS $(1.33 \pm 0.2$ vs. $1.23 \pm 0.13 ; \mathrm{P}=0.289$ for $\mathrm{mRNA})$ and $(1.66 \pm 0.28$ vs. $1.84 \pm 0.21 ; \mathrm{P}=0.361$ for protein).

Effects of LPS, compound $C$ and metformin on CAT. LPS resulted in a moderate but statistically significant increase in CAT mRNA $(1.3 \pm 0.24$ vs. $1.0 \pm 0.24 ; \mathrm{P}=0.042)$ and protein $(1.23 \pm 0.15$ vs. $1.0 \pm 0.21 ; \mathrm{P}=0.029)$ expression levels in cultured 


\section{Superoxide dismutase (mRNA)}

A

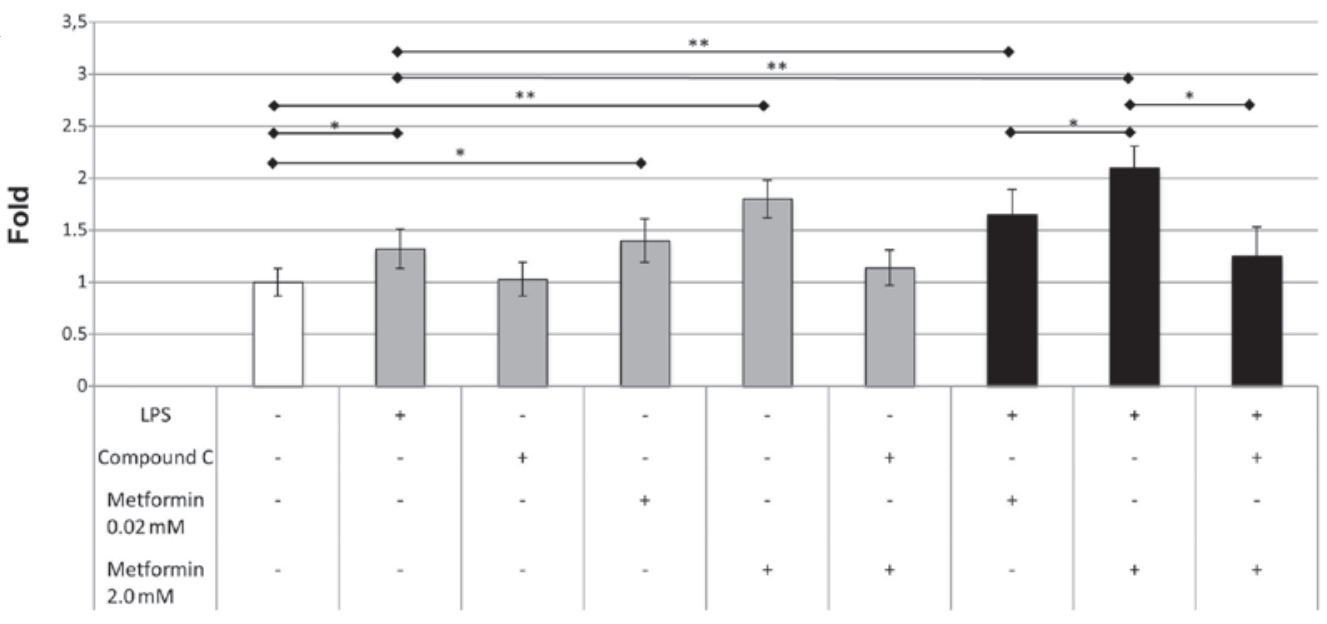

Superoxide dismutase (protein)

B

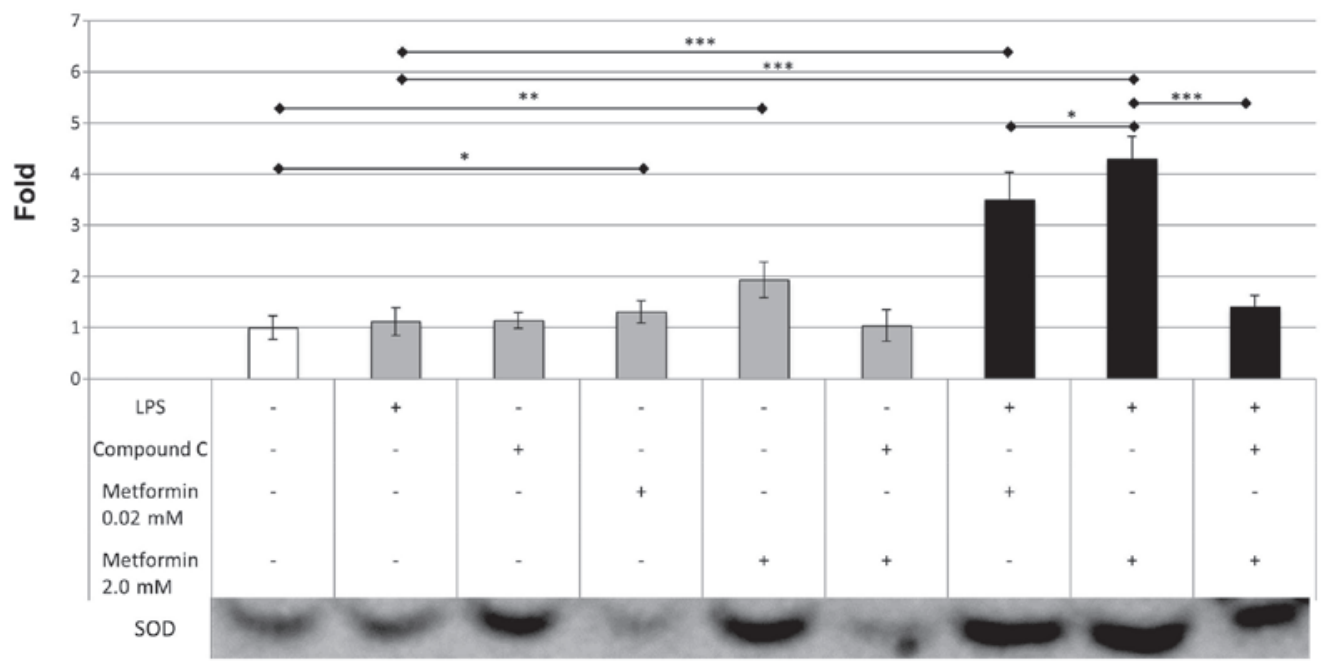

Figure 3. Influence of LPS, metformin and compound $\mathrm{C}$ on the expression of superoxide dismutase mRNA and protein, assessed using (A) reverse transcription-quantitative polymerase chain reaction and (B) western blot analysis, respectively. ${ }^{*} \mathrm{P}<0.05 ;{ }^{* *} \mathrm{P}<0.001 ;{ }^{* * *} \mathrm{P}<0.001$. LPS, lipopolysaccharide.

macrophages. In $2.0 \mathrm{mM}$ metformin-treated samples a mild elevation in CAT mRNA expression was observed (1.35 \pm 0.22 vs. $1.0 \pm 0.24 ; \mathrm{P}=0.027)$; however, $0.02 \mathrm{mM}$ metformin did not induce a significant effect on CAT mRNA. Notably, metformin elevated CAT protein synthesis by a similar degree in the $0.02 \mu \mathrm{M}$ $(1.21 \pm 0.15$ vs. $1.0 \pm 0.21 ; \mathrm{P}=0.049)$ and $2.0 \mu \mathrm{M}(1.26 \pm 0.15$ vs. $1.0 \pm 0.21 ; \mathrm{P}=0.037)$ groups of macrophages. In LPS-treated macrophages, the CAT mRNA level was significantly increased by treatment with $0.02 \mu \mathrm{M}(1.54 \pm 0.18$ vs. $1.3 \pm 0.24 ; \mathrm{P}=0.023)$ and $2.0 \mu \mathrm{M}(1.76 \pm 0.25$ vs. $1.3 \pm 0.24 ; \mathrm{P}=0.003)$ metformin. However, similar changes in protein expression were not observed. Compound $\mathrm{C}$ inhibited the influence of $2.0 \mathrm{mM}$ metformin on CAT mRNA expression in LPS-treated macrophages $(1.32 \pm 0.21$ vs. $1.76 \pm 0.25 ; \mathrm{P}=0.005)$, without a significant effect on CAT protein expression (Fig. 5).

\section{Discussion}

The results of the present study indicate that metformin significantly affected the expression of enzymes associated with oxidative stress. In macrophages modeling an inflammatory situation, induced using LPS, a marked increase in $\mathrm{p} 22^{\text {phox }}$ was observed and a dose-dependent reduction in $\mathrm{p} 22^{\text {phox }}$ expression was observed in cells treated additionally with increasing doses of metformin. These changes were accompanied by increased expression of SOD and GPx. By contrast, the effect of metformin on CAT expression levels in the LPS-treated macrophages was relatively small.

Oxidative stress is necessary for the control of exogenous potentially harmful stimuli, such as bacterial infection. p22 $2^{\text {phox }}$ is the primary source of ROS, and this enzyme is predominantly located in the mitochondria. Metformin is a key factor in the homeostasis of energy expenditure, and is also predominantly located in the mitochondria. The generation of ROS requires high amounts of energy. The results of the present study suggest that metformin reduced the expression of p22 $2^{\text {phox }}$ in LPS-treated macrophages. It was hypothesized that this effect was mediated by AMPK activation, which was confirmed by experiments employing compound $\mathrm{C}$, a pharmacological inhibitor of AMPK. These results are consistent 
Glutathione peroxidase (mRNA)

A

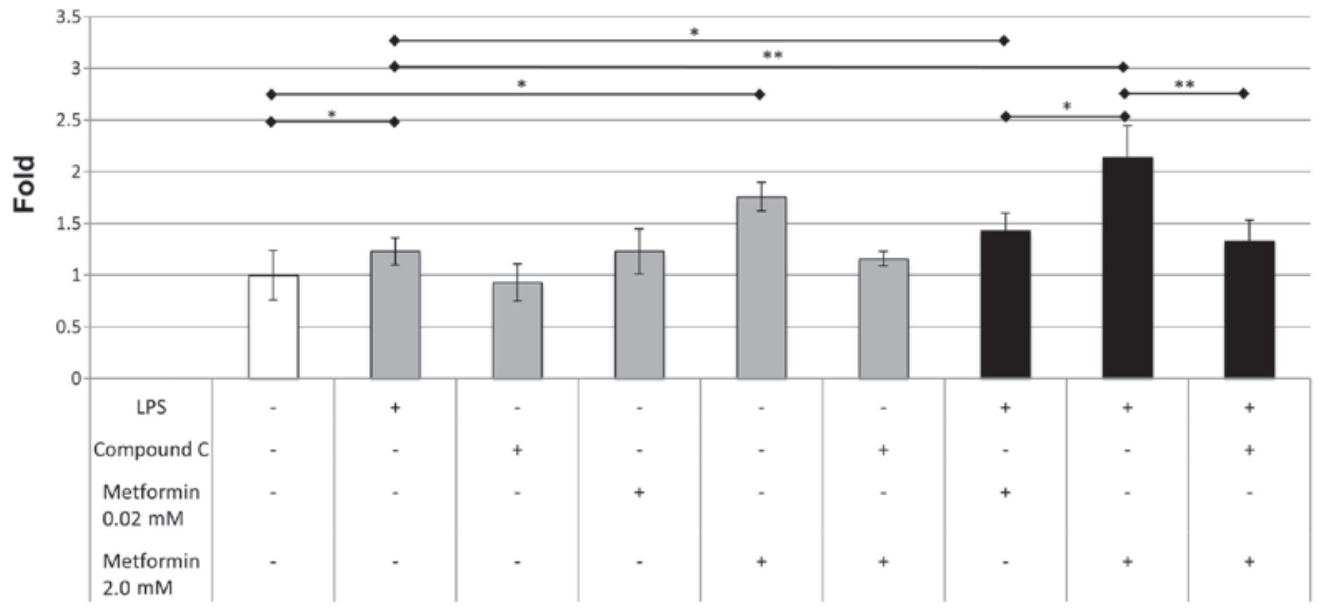

Glutathione peroxidase (protein)

B

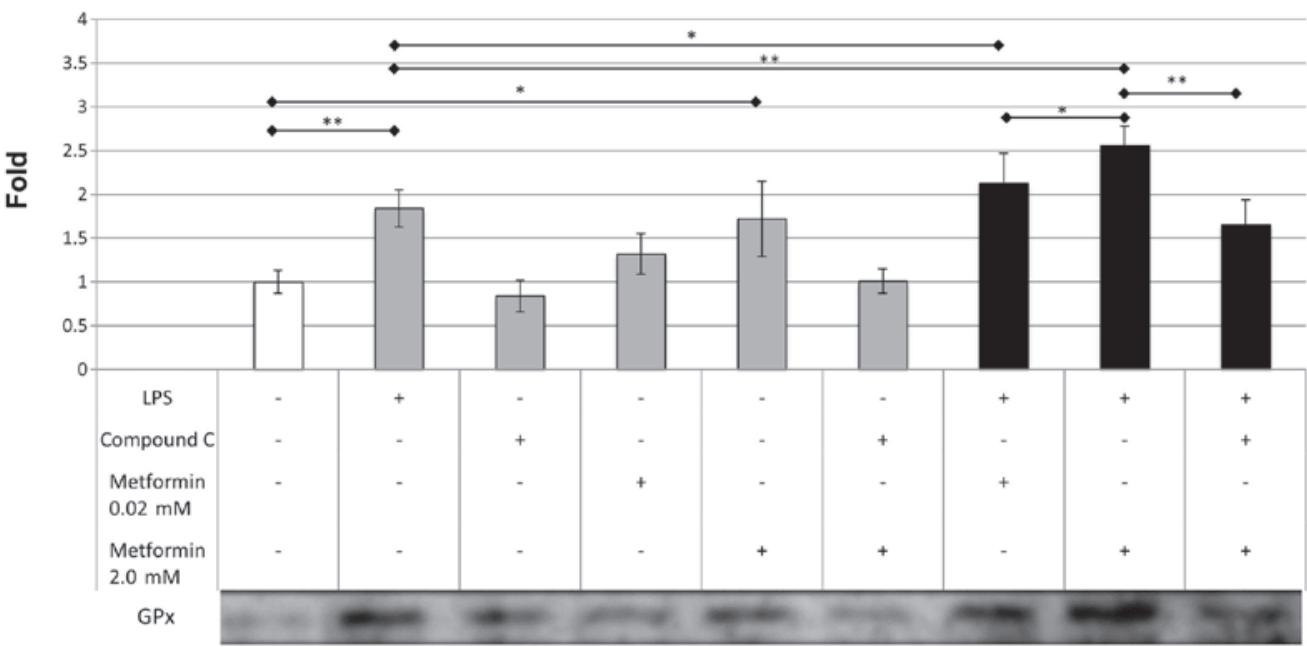

Figure 4. Influence of LPS, metformin and compound C on the expression of glutathione peroxidase mRNA and protein, assessed using (A) reverse transcription-quantitative polymerase chain reaction and (B) western blot analysis, respectively. ${ }^{*} \mathrm{P}<0.05 ;{ }^{* *} \mathrm{P}<0.001$. LPS, lipopolysaccharide.

with the results of previous studies on murine podocytes and human endothelial cells $(22,23)$. Furthermore, a previous study reported that metformin reduced ROS generation by inhibition of respiratory chain complex-1 (24). The results of our previous study indicate that metformin dose-dependently reduces ROS generation in macrophages treated with LPS (1), and the current findings suggest that using higher concentrations of metformin is markedly more effective for reducing $\mathrm{p} 22^{\text {phox }}$ expression. However, it is notable that the reduction of $\mathrm{p} 22^{\text {phox }}$ expression was not observed in unstimulated cells, which may be because AMPK activation is a crucial regulator of oxidative stress in cells subjected to inflammatory conditions, and it does not significantly affect redox status in cells that have not been subjected to LPS.

In our previous study, it was observed that metformin was able to reduce ROS production in LPS-stimulated macrophages. These results were associated with increased activity of antioxidative enzymes (1). The current study investigated the effect of metformin on the expression levels of major antioxidative enzymes that react to mitigate oxidative stress. ROS elimination is a multistage process (25), firstly superoxides are converted into $\mathrm{H}_{2} \mathrm{O}_{2}$ by SOD. Subsequently, CAT converts excessive quantities of $\mathrm{H}_{2} \mathrm{O}_{2}$ into water, or alternatively GPx deactivates $\mathrm{H}_{2} \mathrm{O}_{2}$ using glutathione (26). Antioxidative enzymes are essential elements of the acute reaction of macrophages against infection. The action of these enzymes is necessary in the resolution phase of inflammation and prevents excessive damage of peripheral tissue. The present results suggest that these enzymes may serve a crucial function in the prevention of atherosclerosis. Furthermore, the present results demonstrated that an upregulation of SOD and GPx occurred in macrophages treated with LPS. Perrotta et al reported that increased MnSOD expression may mitigate the cytotoxic effects of oxidized low-density lipoprotein in aortic atheromas (27). In addition, chronic inflammation has been associated with reduced expression of SOD and GPX in patients undergoing hemodialysis (28). In previous animal models, SOD and GPx deficiency have led to increased rates of foam cell formation, increased regional inflammation and ultimately to the progression of atherosclerosis $(29,30)$. Therefore, a therapy that is able to effectively reduce blood glucose in addition to increasing antioxidative potential may underlie 


\section{Catalase (mRNA)}

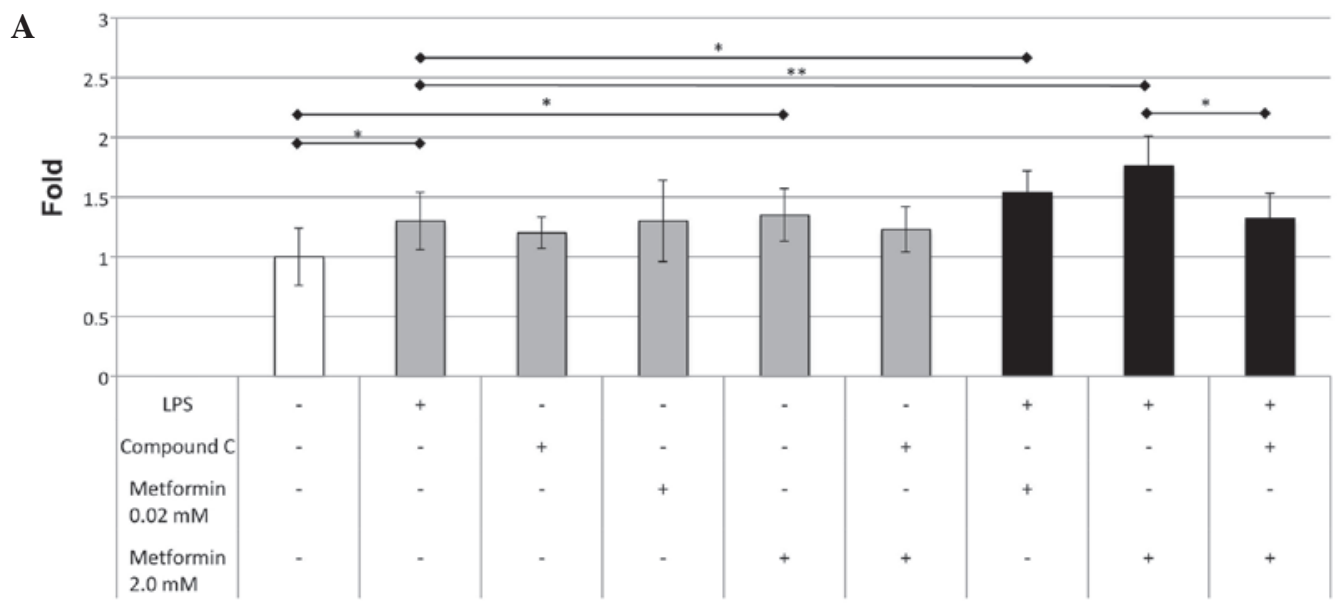

Catalase (protein)

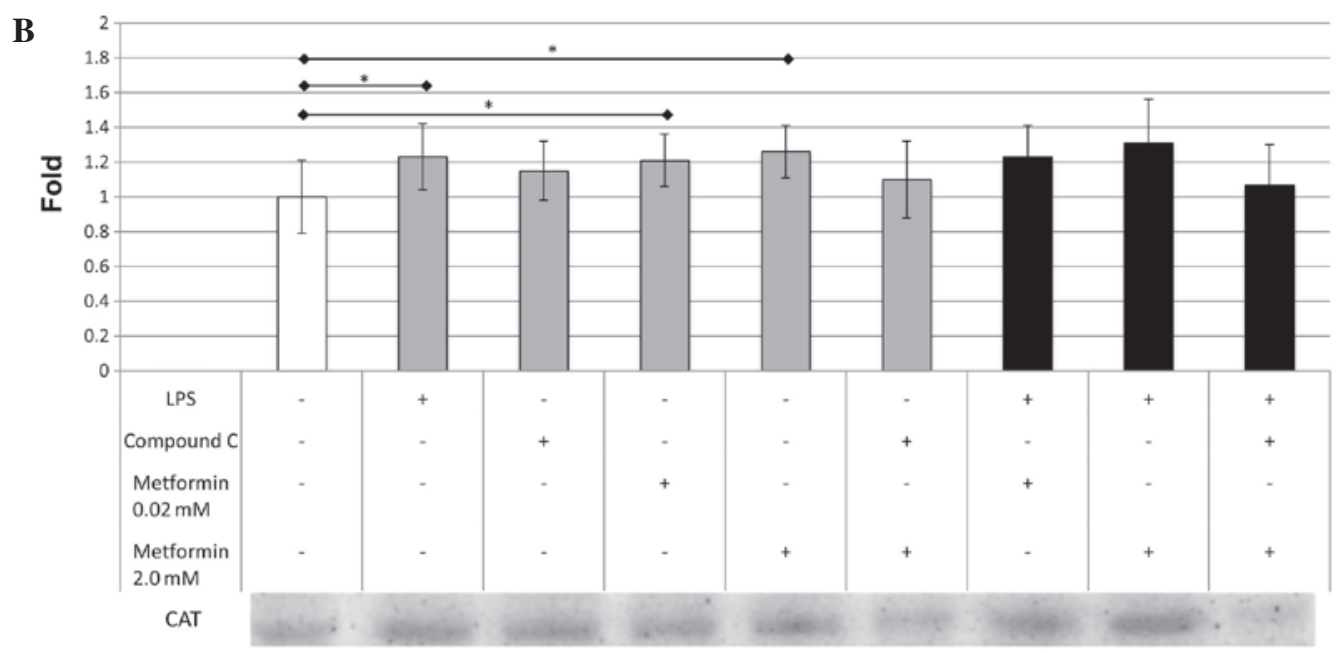

Figure 5. Influence of LPS, metformin and compound $\mathrm{C}$ on the expression of catalase mRNA and protein, assessed using (A) reverse transcription-polymerase chain reaction and (B) western blot analysis, respectively. ${ }^{*} \mathrm{P}<0.05 ;{ }^{* *} \mathrm{P}<0.001$. LPS, lipopolysaccharide.

the additional pleiotropic properties, for example, anticancer activity, of this biguanide drug (31).

In the current study, metformin generally caused only a moderate increase in CAT mRNA and protein expression. These observations were unexpected in light of our previous results, which indicated increased CAT activity in macrophages pretreated with LPS (1). There are a number of potential explanations for these contradictory results: i) Metformin exerts a mild effect on CAT expression, and the results may become statistically significant in experiments including a substantial increase in sample size; ii) a predominant effect of metformin on the catalytic activity of the CAT enzyme; iii) the majority of $\mathrm{H}_{2} \mathrm{O}_{2}$ is converted in macrophages by GPx; or iv) CAT plays an insignificant role in the pathology of atherosclerosis. Other researchers have noted that CAT expression is less affected by inflammation compared with that of GPx in human monocytes (32). However, an inherited CAT deficiency may lead to numerous diseases, including diabetes mellitus (33). Furthermore, certain haplotypes of CAT may prevent atherosclerotic plaque formation (34). Hormonal replacement therapy increases CAT activity, which coincides with improved cardiovascular outcomes, supporting the hypothesis that CAT is a key factor in the prevention of atherosclerosis. According to the current results and those of our previous study, metformin may affect the activity of CAT but not its expression. In addition, novel methods of delivering antioxidative enzymes into atherosclerotic plaques using macrophages enriched in CAT or SOD-mimicking agents are currently under development and have presented promising results (35).

In summary, the present results indicate that metformin significantly alters the expression of enzymes associated with the induction and resolution of oxidative stress. The effect was AMPK-dependent and predominantly observed in $\mathrm{p} 22^{\text {phox }}, \mathrm{SOD}$ and GPx. As a result, a pattern of enzymatic expression indicating an antioxidative profile was observed. These results improve our understanding of the pleiotropic effects of metformin that in addition to its glucose lowering properties, and may provide a basis for further studies to investigate other groups of drugs that may exert beneficial effects by their influence on oxidative stress. The present study had a number of limitations: i) An in vitro setting may not fully reproduce the myriad interactions 
in living organisms; and ii) high concentrations of metformin may induce effects that are not observed in humans; however, the results indicate that in order to mimic long-lasting effects of drugs in living organisms it is necessary to perform in vitro cultures with supraphysiological drug concentrations.

\section{Acknowledgements}

This study was supported by statutory grants from the Medical University of Silesia (no. KNW-1-097/N/4/0 and KNW-1-093/N/5/0). The authors thank Mrs. Jarosława Sprada and Mrs. Halina Klimas for their technical support.

\section{References}

1. Bułdak Ł, Łabuzek K, Bułdak RJ, Kozłowski M, Machnik G, Liber S, Suchy D, Duława-Bułdak A and Okopień B: Metformin affects macrophages' phenotype and improves the activity of glutathione peroxidase, superoxide dismutase, catalase and decreases malondialdehyde concentration in a partially AMPK-independent manner in LPS-stimulated human monocytes/macrophages. Pharmacol Rep 66: 418-429, 2014.

2. Van Greevenbroek MM, Schalkwijk CG and Stehouwer CD: Obesity-associated low-grade inflammation in type 2 diabetes mellitus: Causes and consequences. Neth J Med 71: 174-187, 2013

3. Jin C and Flavell RA: Innate sensors of pathogen and stress: Linking inflammation to obesity. J Allergy Clin Immunol 132: 287-294, 2013.

4. Kaptoge S, Seshasai SR, Gao P, Freitag DF, Butterworth AS, Borglykke A, Di Angelantonio E, Gudnason V, Rumley A, Lowe GD, et al: Inflammatory cytokines and risk of coronary heart disease: New prospective study and updated meta-analysis. Eur Heart J 35: 578-589, 2014.

5. Savoia C and Schiffrin EL: Vascular inflammation in hypertension and diabetes: Molecular mechanisms and therapeutic interventions. Clin Sci (Lond) 112: 375-384, 2007.

6. Ridker PM: High-sensitivity C-reactive protein: Potential adjunct for global risk assessment in the primary prevention of cardiovascular disease. Circulation 103: 1813-1818, 2001.

7. Madej A, Bołdys A, Bułdak L, Labuzek K, Basiak M and Okopień B: Short-term antihypertensive therapy lowers the C-reactive protein level. Postepy Hig Med Dosw (Online) 66: 78-84, 2012.

8. Ridker PM, Danielson E, Fonseca FA, Genest J, Gotto AM Jr, Kastelein JJ, Koenig W, Libby P, Lorenzatti AJ, MacFadyen JG, et al; JUPITER Study Group: Rosuvastatin to prevent vascular events in men and women with elevated C-reactive protein. N Engl J Med 359: 2195-2207, 2008.

9. Deo SH, Fisher JP, Vianna LC, Kim A, Chockalingam A, Zimmerman MC, Zucker IH and Fadel PJ: Statin therapy lowers muscle sympathetic nerve activity and oxidative stress in patients with heart failure. Am J Physiol Heart Circ Physiol 303: H377-H385, 2012.

10. Pignatelli P, Carnevale R, Di Santo S, Bartimoccia S, Nocella C, Vicario T, Loffredo L, Angelico F and Violi F: Rosuvastatin reduces platelet recruitment by inhibiting NADPH oxidase activation. Biochem Pharmacol 84: 1635-1642, 2012.

11. UK Prospective Diabetes Study (UKPDS) Group: Effect of intensive blood-glucose control with metformin on complications in overweight patients with type 2 diabetes (UKPDS 34). Lancet 352: 854-865, 1998.

12. Prasad K and Dhar I: Oxidative stress as a mechanism of added sugar-induced cardiovascular disease. Int J Angiol 23: 217-226, 2014

13. Costa A, Scholer-Dahirel A and Mechta-Grigoriou F: The role of reactive oxygen species and metabolism on cancer cells and their microenvironment. Semin Cancer Biol 25: 23-32, 2014.

14. Park JG and Oh GT: The role of peroxidases in the pathogenesis of atherosclerosis. BMB Rep 44: 497-505, 2011.

15. Okopień B, Krysiak R, Kowalski J, Madej A, Belowski D, Zieliński M and Herman ZS: Monocyte release of tumor necrosis factor-alpha and interleukin-1beta in primary type $\mathrm{IIa}$ and $\mathrm{IIb}$ dyslipidemic patients treated with statins or fibrates. J Cardiovasc Pharmacol 46: 377-386, 2005.
16. Labuzek K, Liber S, Gabryel B, Adamczyk J and Okopień B: Metformin increases phagocytosis and acidifies lysosomal/endosomal compartments in AMPK-dependent manner in rat primary microglia. Naunyn Schmiedebergs Arch Pharmacol 381: 171-186, 2010.

17. Bułdak Ł, Łabuzek K, Bułdak RJ, Machnik G, Bołdys A and Okopień B: Exenatide (a GLP-1 agonist) improves the antioxidative potential of in vitro cultured human monocytes/macrophages. Naunyn Schmiedebergs Arch Pharmacol 388: 905-919, 2015 .

18. Rebelato E, Mares-Guia TR, Graciano MF, Labriola L, Britto LR, Garay-Malpartida HM, Curi R, Sogayar MC and Carpinelli AR: Expression of NADPH oxidase in human pancreatic islets. Life Sci 91: 244-249, 2012

19. Kasperczyk A, Machnik G, Dobrakowski M, Sypniewski D, Birkner E and Kasperczyk S: Gene expression and activity of antioxidant enzymes in the blood cells of workers who were occupationally exposed to lead. Toxicology 301: 79-84, 2012.

20. Strzalka-Mrozik B, Prudlo L, Kimsa MW, Kimsa MC, Kapral M, Nita $M$ and Mazurek U: Quantitative analysis of SOD2, ALDH1A1 and MGST1 messenger ribonucleic acid in anterior lens epithelium of patients with pseudoexfoliation syndrome. Mol Vis 19: 1341-1349, 2013

21. Rice P, Longden I and Bleasby A: EMBOSS: The European Molecular Biology Open Software Suite. Trends Genet 16: 276-277, 2000.

22. Piwkowska A, Rogacka D, Jankowski M, Dominiczak MH, Stepiński JK and Angielski S: Metformin induces suppression of $\mathrm{NAD}(\mathrm{P}) \mathrm{H}$ oxidase activity in podocytes. Biochem Biophys Res Commun 393: 268-273, 2010.

23. Batchuluun B, Inoguchi T, Sonoda N, Sasaki S, Inoue $T$, Fujimura Y, Miura D and Takayanagi R: Metformin and liraglutide ameliorate high glucose-induced oxidative stress via inhibition of PKC-NAD $(\mathrm{P}) \mathrm{H}$ oxidase pathway in human aortic endothelial cells. Atherosclerosis 232: 156-164, 2014.

24. Batandier C, Guigas B, Detaille D, El-Mir MY, Fontaine E, Rigoulet $\mathrm{M}$ and Leverve XM: The ROS production induced by a reverse-electron flux at respiratory-chain complex 1 is hampered by metformin. J Bioenerg Biomembr 38: 33-42, 2006.

25. Lu W, Ogasawara MA and Huang P: Models of reactive oxygen species in cancer. Drug Discov Today Dis Models 4: 67-73, 2007.

26. Krifka S, Hiller KA, Spagnuolo G, Jewett A, Schmalz G and Schweikl H: The influence of glutathione on redox regulation by antioxidant proteins and apoptosis in macrophages exposed to 2-hydroxyethyl methacrylate (HEMA). Biomaterials 33: 5177-5186, 2012.

27. Perrotta I, Perrotta E, Sesti S, Cassese M and Mazzulla S: MnSOD expression in human atherosclerotic plaques: An immunohistochemical and ultrastructural study. Cardiovasc Pathol 22: 428-437, 2013

28. Ari E, Kaya Y, Demir H, Cebi A, Alp HH, Bakan E, Odabasi D and Keskin S: Oxidative DNA damage correlates with carotid artery atherosclerosis in hemodialysis patients. Hemodial Int 15: 453-459, 2011.

29. Fukai T and Ushio-Fukai M: Superoxide dismutases: Role in redox signaling, vascular function and, diseases. Antioxid Redox Signal 15: 1583-1606, 2011

30. Cheng F, Torzewski M, Degreif A, Rossmann H, Canisius A and Lackner KJ: Impact of glutathione peroxidase-1 deficiency on macrophage foam cell formation and proliferation: Implications for atherogenesis. PLoS One 8: e72063, 2013.

31. Rizos CV and Elisaf MS: Metformin and cancer. Eur J Pharmacol 705: 96-108, 2013.

32. Szuchman-Sapir A, Etzman M and Tamir S: Human atherosclerotic plaque lipid extract impairs the antioxidant defense capacity of monocytes. Biochem Biophys Res Commun 423: 884-888, 2012.

33. Góth L and Nagy T: Inherited catalase deficiency: Is it benign or a factor in various age related disorders? Mutat Res 753: 147-154, 2013.

34. Nivet-Antoine V, Labat C, El Shamieh S, Dulcire X, Cottart CH, Beaudeux JL, Zannad F, Visvikis-Siest $\mathrm{S}$ and Benetos A: Relationship between catalase haplotype and arterial aging. Atherosclerosis 227: 100-105, 2013.

35. Lee S: Monocytes: A novel drug delivery system targeting atherosclerosis. J Drug Target 22: 138-145, 2014. 